\title{
Effect of Phosphorus Fertilizer on Brassica Napusl (B.N) Oil and Protein in Water Fed Cultivation in Different Groups of Soil Phosphor Fertility
}

\author{
Ebrahim Fattahinejad \\ Department of Soil Sciences, Behbahan Branch, Islamic Azad University, Behbahan, Iran.
}

\begin{abstract}
How to cite this paper: Ebrahim Fattahinejad. (2020) Effect of Phosphorus Fertilizer on Brassica Napusl (B.N) Oil and Protein in Water Fed Cultivation in Different Groups of Soil Phosphor Fertility. International Journal of the Science of Food and Agriculture, 4(4), 511-518. DOI: $10.26855 /$ ijfsa.2020.12.020
\end{abstract}

Received: November 11, 2020

Accepted: December 20, 2020

Published: January 4, 2021

*Corresponding author: Ebrahim Fattahinejad, Department of Soil Sciences, Behbahan Branch, Islamic Azad University, Behbahan, Iran. Email: Ebrahim_fatahi88@yahoo.com

\begin{abstract}
To find out the effect of phosphorus fertilizer on the canola oil and proteintype 401 Hayola in water fed cultivation in different groups of soil phosphor fertility 16 tests have been conducted in 4 different areas and in each area 4 test in 4 groups of phosphor usable in soil (less than 3ppm, 3-6 ppm, 6-10ppm and more than $10 \mathrm{ppm})$ in complete random block design in 4 phosphorous treatment $(0$, $25,50,75$, kgs in $\mathrm{p}_{2} \mathrm{O}_{5}$ in each hectare). From triple super phosphate source in 4 repetition in the city of Behbahan, it has been conducted for two agricultural year of 2011-2012. Results obtain show that the phosphor fertilizer treatment in all soil fertility groups, it had no meaningful effect on the percentage of oil and protein. On the one hand there has been a meaningful and negative coordination between seed protein and percentage of oil $(\mathrm{r}=-0 / 53)$ and a strong and meaningful coordination between oil functioning and seed's functioning ( $\mathrm{r}=0 / 79)$.
\end{abstract}

\section{Keywords}

Canola, Phosphorus, Oil, Protein

\section{Introduction}

Brassica Napusl (B.N) is among the oil producing plant and plays an important role in the human nutrition through extracted oil. It also plays an important role in the provision of animals and birds food [1]. This plant is very important due to its consisting $40 \%$ oil in the seed and $40 \%$ protein in its meal or oil cake [2-3]. High amount of oil in the CANOLA and also suitable fat acids composition of corrected type caused its dominance on the world market. Since more than $90 \%$ of the country's oil is being imported from other countries, therefore considering this plant is important [3]. Timely and proper uses of nutritious elements are the most important ways of increasing the seeds functioning, oil and improvement in the quality of CANOLA seeds [1-4]. CANOLA highly needs nutritious elements and most of agricultural fields which are used for production of this plant are in short of one or more nutritious elements for producing enough oil or protein [1-4]. Phosphate is one of the needed elements for CANOLA suitable and correct use of phosphate cause increase in the production of oil and protein in CANOLA proper use of fertilizer are among the good work in the agriculture which effects the productivity and quality of products. Phosphate feeding in CANOLA cultivation has important effect on the production of oil seeds, shortage of phosphate causes reduction of oil from 33 to 23 percent. Also excess use of phosphate reduction in the amount of CANOLA oil seed [5]. In their researches reported that phosphate fertilizer doesn't have important effect on the CANOLA oil seed [8]. Gupta and Das [9] reported that phosphate has no effect on the CANOLA oil seed or otherwise its effect is very less. Singh and Tomar [10] mentioned that phosphate does not have considering effect on the CANOLA oil seed and at the time of deciding regarding the use of phosphate fertilizer it is not necessary to consider the increase in the percentage of oil. Grant and Billy [11] mentioned that suitable amount of phosphate used can increase the percentage of oil and protein. Pinkerton [12] mentioned that the highest percentage of oil is obtained when the amount of soil's phosphate is average which is due to nitrogen and phosphate. MirzaKhani et al [13] in their research on the safflower reported that the percentage of oil in the seed is mainly 
due to effect of plant's genotype and nutritious condition.

They reported that with the increase in the nutritious elements amounts the plant growth wolill increase and causes increase in the percentage of seed's protein and since protein percentage and oil percentage are opposite to each other, therefore it causes reduction in the seed's oil production. Holmes and Ansiley [6-7], Jessen [14], Wetter et al. [8] in their researches mentioned that phosphate fertilizer has less effect on the CANOLA seed's protein. Mejamdar and Sendhu [15] reported that phosphate fertilizer causes reduction of more than $1 \%$ in the protein seed of brown SARSAN. Finelison and colleagues [16] mentioned in some conditions phosphate fertilizer effect the nitrogen composition of CANOLA seed and the amount of FreeAmino Acids (Argenin \& Prolin) will increase. But this effect is very less and totally the protein seed very less will be effected by the phosphate. Generally, the amount of CANOLA oil and protein will not be effected by phosphate fertilizers. Also, there are some reports regarding the negative coordination between oil and protein seeds of CANOLA Helmoz and Ansiley [6-7] $\odot$, Mojemdar and Sendhu [15] $\odot$, Wetter et al. [8] $\odot$, Mohammadi Nikipoor [17], also mentioned a negative and meaningful coordination between percentage of oil and protein. Ojagloo et al. [18] in their research on the Safflower plant noticed a negative and meaningful coordination between percentage of oil and protein seeds. Ghavaee et al. [19] about the CANOLA plant reported that with the use of sulfur the percentage of oil will decrease and they mentioned that the reason for it is negative coordination between oil and protein in oil seeds.

\section{Materials and Methods}

Test has been conducted in the city of Behbahan in the south east of Khozistan province with the longitude of $50^{\circ} 12$ east and latitude of $30^{\circ} 36$ north with the height of 320 meters from the sea level. Behbahn is an area with semi deserted climate and located in STEPPE hot climate. Mean rain fall and 10 years temperature average equal to 313/5 millimeters and 25 degree centigrade.

To find out the effect of phosphate fertilizer on the CANOLA oil and protein in the water fed cultivation in different groups of phosphate fertility soil, 16 test in 4 areas have been conducted. In each area, 4 tests in 4 phophate group usable in the the soil (less than 3ppm, between 3-6 ppm, between 6-10 ppm, and more than 10ppm) in the form of complete random block design in 4 phosphate fertilizer treatment $\left(0,25,50,75\right.$, $\mathrm{kg}$ in $\mathrm{P}_{2} \mathrm{O}_{5}$ hectare) from the triple super phosphate source in 4 repetitions have been conducted which means that a test has been done in each group of soil fertility according to the amount of phosphate usable in the form of complete random block designs in 4 phosphorous fertilizer treatment in 4 repetitions. The space between 4 areas is equal to 35-50 kilometers and space between field and each area is between 3-5 centimeters. Therefore, each test consisted of 16 terraces. Each terrace with the length of 5 meters with 8 cultivated line at the space of 30 centimeters and the space between bushes are 5 meters, also the between each terrace 1.5 meter from each side and repetition spaces were also 1.5 meter. The date of cultivation was coincidence with the first rain fall in autumn in the area. Hoyola 401 was used in the test. The method of cultivation was in serial and the amount of seeds used was 8 kilograms in hectare. In all, the treatments $60 \mathrm{~kg} / \mathrm{ha}$ pure nitrogen $(1 / 2 \mathrm{base}+1 / 2$ at the time of shooting) from the urea sources and 50 kilogram in hectare $\mathrm{K}_{2} \mathrm{O}$ for sulfate potassium were used as bases. Removal after saddles ripening was at the level of $\left(4 * 1.5\right.$ meters or $\left.6 \mathrm{~m}^{2}\right)$ in each terrace and the seed's functioning with $10 \%$ moisture was determined and calculated in each hectare. Seed and strew samples were sent to the library for test regarding oil, protein and phosphate content. Protein was measured with the KEJALDAL method and oil was measured with the method of SOKSELE.

In this research, MSTAT.C software was used for statistical analysis. Means comparison have been done according to LSD test. Variance analysis for two agricultural year of 2011-2012 has been surveyed according to variance analysis.

\section{Result and discussion}

\subsection{Percentage and Function of Oil}

Results obtained from complex variance analysis showed less than $3 \mathrm{ppm}$ for two agricultural year phosphate fertility group absorbable in soil. The effect of phosphate fertilizer treatment and mutual effect (phosphate fertilizer * fertility group) on the percentage of oil and CANOLA oil function is not meaningful. But the mutual effect (areas * fertility group) on the oil functioning is meaningful (Table 1). Also according to results from Table 5 of LSD test, there is not a meaningful difference between phosphate fertilizer treatment with witness treatment regarding oil and oil functioning and therefore in phosphate fertilizer treatment percentage of oil in relation to witness is little, but does not have meaningful effect. In phosphate fertility 3-6 ppm according to results from Table 2 effect of phosphate fertilizer and mutual effect (phosphate fertilizer * fertility group) on the oil functioning is meaningful. Results obtained from Table 6 showed that there is not a meaningful difference between phosphate fertilizer treatment and witness trmeatent. Also in phosphate fertility group 6-10 ppm the effect of phosphate fertilizer and mutual effect (phosphate fertilizer * fertility group) wasn't meaningful, but mutual effect (areas * fertility group) on the oil functioning is meaningful. On one hand, according to LSD test, there was not a meaningful difference between phosphate fertilizer treatment and witness treatment (Tables $3 \&$ 7). In soil phosphate fertility group of more than $10 \mathrm{ppm}$ results obtained from Table 4 show that the phos- 
phate fertilizer treatment and mutual effect(phosphate fertilizer * fertility group) do not have meaningful effect on the percentage of oil and its functioning. But the mutual effect (areas * fertility group) has meaningful effect on the oil functioning. Also according to Table 8, there is not any difference between phosphate fertilizer treatment and witness treatment. And in some fertilizer treatment the amount of oil in relation to witness treatment is less. Considering the test results it can be said that even though phosphorous fertilizer does not have much effect on the CANOLA oil percentage, but in soil with less or very less absorbable phosphate, suitable use of phosphate fertilizer can cause improvement in the condition of CANOLA oil and oil functioning. Boss [5] reported that phosphorous treatment to the CANOLA causes important effect on the oil seed and in high shortage of phoaphate the amount of oil reduces from $33 \%$ to $23 \%$. Holmes and Ainsley [6-7], : $:$ Wetter et al [8], : $:$ Gupta and Das [9] mentioned that the phosphate fertilizer does not have considerable effect on the CANOLA seed. Singhand Tomar [10] said that while deciding about phosphate fertilizer there is no reason to think of the percentage of oil. Of course in the soils which are poor in phosphate, use of enough phosphate is effective in the amount of oil and its functioning. Sajed et al. [20] in a research on the medicine plant of paper seed pumpkins percentage reported that phosphate fertilizer does not have meaningful effect on the seed oil amount.

\subsection{Protein Percentage}

from the results obtained from complex variance analysis for two agricultural year in soil fertility group of less than 3 ppm on the percentage of protein show that the effect of phosphate fertilizer treatment and also the mutual effect (phosphate fertilizer * fertility group) is not meaningful (Table 1). On the one hand, according to results obtained from Table [5] and LSD test there isn't a meaningful difference between phosphate fertilizer treatment with witness treatment regarding the percentage of protein. Even though protein percentage in fertilizing treatment is little more than witness treatment but the difference is not meaningful. In phosphate fertility group 3-6 ppm according to the results obtained from Table 2, the effect of phosphate fertilizer and mutual effect (phosphate fertilizer * fertility group) on the percentage of protein is not meaningful. Also, the average comparison of phosphate fertilizer treatment with witness treatment according to LSD test is not different (Table 6). Results obtained from the compound variance analysis in two agricultural year in fertility group of 6-10 ppm has been shown regarding the percentage of protein. The effect of phosphate fertilizer and mutual effect (fertilizer * fertility group) in this group had no meaningful effect on the percentage of protein. On the one hand, according to LSD test regarding average comparisons of phosphate treatments with witness treatment there is not a meaningful difference regarding the percentage of protein and all are located in one group (Tables $3 \&$ 7). In phosphate fertility group of more than $10 \mathrm{ppm}$ the results obtained from Table 4 show that the effect of phosphate fertilizer treatment and mutual effect (phosphate fertilizer * fertility group) does not have meaningful effect on the percentage of protein. Also, according to the result from Table 8 and LSD test, there is no difference between phosphate fertilizer treatment with average witness treatment. According to the results obtained from test it can be said that the amount of CANOLA seed protein less effected by phosphate fertilizer. Holms and Ainsley [6-7] $\otimes$, Jessen [14] $\otimes$, Wetter et al. [8] reported that phosphate fertilizer has a little effect on the CANOLA seed's protein. Mejumdar and Sendho [15] in a research on the brown SARSON reported that phosphate fertilizer cause reduction of more than $1 \%$ on the seed's protein.

\subsection{Coordination between Function, Oil and Protein of CANOLA Seed}

Results obtained from Table 9 show that there is a meaningful and negative coordination between percentage of oil and percentage of protein $\left(\mathrm{r}=-0 / 53^{* *}\right)$. May be the reason for it is the use of nitrogen fertilizer in all the fertility groups, since nitrogen causes increase in the amount of seed's protein and the direct effect of protein cause reduction in the seed's oil. Coordination between percentage of oil and oil's function is very weak and meaningful $\left(r=0 / 06^{\text {ns }}\right)$, but there is a strong and meaningful coordination between oil function and seed's function $\left(\mathrm{r}=0 / 79^{* *}\right)$, therefore maybe the best way to obtain increase in the oil is seed's function in a unit level. Billy and Grant [11] $\odot$, Holms and Ainsley [6-7] $\odot$, Mejumdar and Sandhu [15]. Wetter et al. [8] have also given reports on the reduction of percentage of oil and increase in the protein of CANOLA plant. Finlay Son et al. [16] mentioned that in some of the conditions phosphate fertilizer has effect on the seeds with nitrogen compositions specially free Amino (Argenin and Prolin) and may be the seed's protein increases a little. Mohammadi Nikpour [17] also in a report on the Safflower reported a negative and meaningful relation between percentage of oil and percentage of protein. Ojaghloo et al. [18] in a research with the aim of producing relation between percentage of protein and percentage of oil reported that use of nitrogen can cause increase in the protein and reduction in the oil of seed. Therefore, for extraction of oil more than nitrogen safflower element should be kept in balance for the use. MirzaKhani et al. [13] reported that use of difference amount of nitrogen and phosphate fertilizer cause meaningful difference through creating better nutritioun condition for the plant safflower in production of seed function and with regard to coordination it is very meaningful and positive ( $\left.\mathrm{r}=0 / 88^{* *}\right)$ which is presented between the seed function and oil function and therefore it can be said that any treatment which causes more seed function, increases the oil function. Gavahi et al. [19] reported that application of 120 kilograms of sulfur in hectare with the average of $38 / 6 \%$ oil in relation to its non application with $31 / 60 \%$ oil cause $3 / 4 \%$ CANOLA seed oil reduction. The reason 
for this is negative coordination between oil percentage and percentage of protein in the oil seeds since sulfur's presence in Amino Acids construction causes increase in the percentage of seed's protein.

Table 1. Compound variance analysis quality properties canola in fertility group soil absorption phosphorus under<3ppm

\begin{tabular}{|c|c|c|c|c|}
\hline \multirow{2}{*}{ Change sources } & \multirow{2}{*}{ Degree freedom } & \multicolumn{3}{|c|}{ Mean squares } \\
\hline & & Oil yiled & Oil percentage & Protein percentage \\
\hline Year & 1 & $12832813 / 8^{* *}$ & $145 / 8^{*}$ & $347 / 86^{*}$ \\
\hline Repetition $\times$ Year & 6 & $9721 / 68^{* *}$ & $3 / 04^{*}$ & $5 / 17^{*}$ \\
\hline Area(A) & 3 & $4522549 / 47^{* *}$ & ${ }^{\mathrm{ns}} 3 / 78$ & ${ }^{\mathrm{ns}} 6 / 43$ \\
\hline Year $\times$ Area & 3 & $3457218 / 12^{* *}$ & ${ }^{\mathrm{n}} 2 / 43$ & ${ }^{\mathrm{ns}} 4 / 13$ \\
\hline Error(A) & 18 & $24043 / 08$ & $4 / 43$ & $7 / 53$ \\
\hline Soil Phosphorus Fertility Groups(B) & 3 & $549229 / 44^{* *}$ & ${ }^{\mathrm{ns}} 3 / 38$ & ${ }^{\mathrm{ns}} 4 / 05$ \\
\hline Fertility Groups $\times$ Area & 3 & $753470 / 64^{* *}$ & ${ }^{\mathrm{ns}} 3 / 03$ & ${ }^{\mathrm{ns}} 5 / 15$ \\
\hline Area $\times$ Fertility Groups & 9 & $286385 / 61^{* *}$ & ${ }^{\mathrm{ns}} 1 / 14$ & ${ }^{\mathrm{ns}} 1 / 94$ \\
\hline Year $\times$ Area $\times$ Fertility Groups & 9 & $588706 / 08^{* *}$ & ${ }^{\mathrm{ns}} 1 / 01$ & ${ }^{\mathrm{ns}} 1 / 72$ \\
\hline Error(B) & 72 & $24211 / 32$ & $1 / 18$ & $2 / 01$ \\
\hline Phosphorus Fertilizer Treatment (C) & 3 & ${ }^{\mathrm{n} n} 192385 / 5$ & ${ }^{\mathrm{ns}} 1 / 03$ & ${ }^{\mathrm{ns}} 1 / 75$ \\
\hline Phosphorus Fertilizer Treatment $\times$ Year & 3 & ${ }^{\mathrm{ns}} 250101 / 15$ & ${ }^{\mathrm{n}} 1 / 03$ & ${ }^{\mathrm{ns}} 1 / 75$ \\
\hline Area $\times$ Phosphorus Fertilizer & 9 & ${ }^{\mathrm{ns}} 206841$ & ${ }^{\mathrm{ns}} 0 / 83$ & ${ }^{\mathrm{ns}} 1 / 41$ \\
\hline Area $\times$ Phosphorus Fertilizer $\times$ Year & 9 & ${ }^{{ }^{\mathrm{n}} 2} 268893 / 3$ & ${ }^{\mathrm{n}} 1 / 08$ & ${ }^{\mathrm{ns}} 1 / 84$ \\
\hline ErrorC $_{1}$ & 36 & 280896 & $1 / 12$ & $1 / 92$ \\
\hline Fertility Groups $\times$ Phosphorus Fertilizer & 9 & ${ }^{\mathrm{ns}} 207951$ & ${ }^{\mathrm{ns}} 0 / 83$ & ${ }^{\mathrm{ns}} 1 / 41$ \\
\hline Phosphorus Fertilizer×Fertility Groups $\times$ Year & 9 & ${ }^{{ }^{n s}} 270336 / 3$ & ${ }^{\mathrm{ns}} 1 / 08$ & ${ }^{\mathrm{ns}} 1 / 84$ \\
\hline Area $\times$ Group $\times$ Phosphorus Fertilizer & 27 & ${ }^{\mathrm{ns}} 57366$ & ${ }^{\mathrm{ns}} 0 / 30$ & ${ }^{\mathrm{ns}} 0 / 51$ \\
\hline Area $\times$ Group $\times$ Phosphorus Fertilizer $\times$ Year & 27 & ${ }^{\mathrm{n} n} 149151 / 6$ & ${ }^{\mathrm{ns}} 0 / 60$ & ${ }^{\mathrm{ns}} 1 / 02$ \\
\hline Error $\mathrm{C}_{2}$ & 108 & 93632 & $0 / 37$ & $0 / 64$ \\
\hline (CV \%) & & $13 / 65$ & $8 / 45$ & $8 / 23$ \\
\hline
\end{tabular}

Table 2. Compound variance analysis, functioning and functioning component canola in phosphorus fertility group soil absorption in group between 3-6 ppm

\begin{tabular}{|c|c|c|c|c|}
\hline \multirow{2}{*}{ Change sources } & \multirow{2}{*}{ Degree freedom } & \multicolumn{3}{|c|}{ Mean squares } \\
\hline & & Oil yiled & Oil percentage & Protein percentage \\
\hline Year & 1 & $7000 / 14^{* *}$ & $322 / 18^{* *}$ & $13 / 44^{* *}$ \\
\hline Repetition $\times$ Year & 6 & ${ }^{\mathrm{ns}} 146 / 16$ & ${ }^{\mathrm{ns}} 21 / 52$ & $0 / 169^{*}$ \\
\hline Area(A) & 3 & ${ }^{\mathrm{ns}} 182 / 18$ & ${ }^{\mathrm{ns}} 11 / 52$ & $0 / 26^{*}$ \\
\hline Year× Area & 3 & ${ }^{\mathrm{ns}} 116 / 65$ & ${ }^{\mathrm{ns}} 55 / 86$ & ${ }^{\mathrm{ns}} 0 / 16$ \\
\hline Error(A) & 18 & $212 / 68$ & $18 / 38$ & $0 / 052$ \\
\hline Soil Phosphorus Fertility Groups(B) & 3 & ${ }^{\mathrm{ns}} 114 / 01$ & $183 / 60^{* *}$ & $1 / 09^{* *}$ \\
\hline Fertility Groups $\times$ Area & 3 & ${ }^{\mathrm{ns}} 145 / 25$ & ${ }^{\mathrm{ns}} 13 / 05$ & $0 / 252^{*}$ \\
\hline Area $\times$ Fertility Groups & 9 & ${ }^{\mathrm{ns}} 54 / 66$ & ${ }^{\mathrm{ns}} 13 / 12$ & ${ }^{\mathrm{ns}} 0 / 084$ \\
\hline Year $\times$ Area $\times$ Fertility Groups & 9 & ${ }^{\mathrm{ns}} 48 / 19$ & ${ }^{\mathrm{ns}} 16 / 98$ & ${ }^{\mathrm{ns}} 0 / 179$ \\
\hline Error(B) & 72 & $56 / 75$ & $17 / 57^{*}$ & $0 / 724$ \\
\hline Phosphorus Fertilizer Treatment (C) & 3 & ns $49 / 56$ & ${ }^{\mathrm{ns}} 17 / 46$ & ${ }^{\mathrm{ns}} 0 / 99$ \\
\hline Phosphorus Fertilizer Treatment $\times$ Year & 3 & ns $48 / 20$ & ${ }^{\mathrm{ns}} 17 / 28$ & ${ }^{\mathrm{ns}} 0 / 97$ \\
\hline Area $\times$ Phosphorus Fertilizer & 9 & ${ }^{\mathrm{ns}} 39 / 86$ & ${ }^{\mathrm{ns}} 14 / 21$ & ${ }^{\mathrm{ns}} 0 / 80$ \\
\hline Area $\times$ Phosphorus Fertilizer $\times$ Year & 9 & ${ }^{\mathrm{ns}} 51 / 83$ & ${ }^{\mathrm{ns}} 18 / 50$ & ${ }^{\mathrm{ns}} 1 / 03$ \\
\hline ErrorC $_{1}$ & 36 & $54 / 14$ & $20 / 63$ & $1 / 134$ \\
\hline Fertility Groups $\times$ Phosphorus Fertilizer & 9 & ${ }^{\mathrm{ns}} 40 / 09$ & ${ }^{\mathrm{ns}} 14 / 21$ & $0 / 79^{\mathrm{ns}}$ \\
\hline Phosphorus Fertilizer×Fertility Groups $\times$ Year & 9 & ${ }^{\mathrm{ns}} 52 / 1$ & ${ }^{\mathrm{ns}} 18 / 51$ & ${ }^{\mathrm{ns}} 1 / 03$ \\
\hline Area $\times$ Group $\times$ Phosphorus Fertilizer & 27 & ${ }^{\mathrm{ns}} 14 / 58$ & ${ }^{\mathrm{ns}} 5 / 38$ & ${ }^{\mathrm{ns}} 0 / 30$ \\
\hline Area $\times$ Group $\times$ Phosphorus Fertilizer $\times$ Year & 27 & ${ }^{\mathrm{ns}} 29 / 00$ & ${ }^{\mathrm{ns}} 10 / 32$ & ${ }^{\mathrm{ns}} 0 / 57$ \\
\hline Error $C_{2}$ & 108 & $18 / 05$ & $6 / 88$ & $0 / 38$ \\
\hline$(\mathrm{CV} \%)$ & & $21 / 4$ & $17 / 04$ & $8 / 64$ \\
\hline
\end{tabular}


Table 3. Compound variance analysis quality properties canola in fertility group soil absorption phosphorus 6-10 ppm

\begin{tabular}{|c|c|c|c|c|}
\hline \multirow{2}{*}{ Change sources } & \multirow{2}{*}{ Degree freedom } & \multicolumn{3}{|c|}{ Mean squares } \\
\hline & & Oil yiled & Oil percentage & Protein percentage \\
\hline Year & 1 & $13217798 / 2^{* *}$ & $126 / 85^{*}$ & $257 / 8^{*}$ \\
\hline Repetition $\times$ Year & 6 & $10013 / 33^{* *}$ & $2 / 64^{*}$ & $5 / 38^{*}$ \\
\hline Area(A) & 3 & $4658225 / 95^{* *}$ & ${ }^{\mathrm{ns}} 3 / 29$ & ns $6 / 69$ \\
\hline Year $\times$ Area & 3 & $3560934 / 66^{* *}$ & ${ }^{\mathrm{ns}} 2 / 11$ & ${ }^{\mathrm{ns}} 4 / 29$ \\
\hline Error(A) & 18 & $24764 / 37$ & $3 / 85$ & $7 / 83$ \\
\hline Soil Phosphorus Fertility Groups(B) & 3 & $565706 / 3^{* *}$ & ${ }^{\mathrm{ns}} 2 / 07$ & ${ }^{\mathrm{ns}} 4 / 21$ \\
\hline Fertility Groups $\times$ Area & 3 & $776074 / 76^{* *}$ & ns $2 / 64$ & ${ }^{\mathrm{ns}} 5 / 36$ \\
\hline Area $\times$ Fertility Groups & 9 & $294977 / 18^{* *}$ & $\begin{array}{ll}{ }^{\text {ns }} 0 / 99 \\
\end{array}$ & ${ }^{\mathrm{ns}} 2 / 02$ \\
\hline Year $\times$ Area $\times$ Fertility Groups & 9 & $606367 / 26^{* *}$ & ns $0 / 88$ & ${ }^{\mathrm{ns}} 1 / 79$ \\
\hline Error(B) & 72 & $24937 / 66$ & $1 / 03$ & $2 / 09$ \\
\hline Phosphorus Fertilizer Treatment (C) & 3 & ${ }^{\mathrm{ns}} 198157 / 06$ & ${ }^{\mathrm{ns}} 0 / 90$ & ${ }^{\mathrm{ns}} 1 / 82$ \\
\hline Phosphorus Fertilizer Treatment $\times$ Year & 3 & ${ }^{\mathrm{ns}} 257604 / 18$ & ${ }^{\mathrm{ns}} 0 / 90$ & ${ }^{\mathrm{ns}} 1 / 82$ \\
\hline Area $\times$ Phosphorus Fertilizer & 9 & ${ }^{\mathrm{ns}} 213046 / 23$ & ${ }^{\mathrm{ns}} 0 / 72$ & ${ }^{\mathrm{ns}} 1 / 47$ \\
\hline Area $\times$ Phosphorus Fertilizer $\times$ Year & 9 & ${ }^{\mathrm{ns}} 276960 / 1$ & ${ }^{\mathrm{ns}} 0 / 94$ & ${ }^{\mathrm{ns}} 1 / 91$ \\
\hline ErrorC $_{1}$ & 36 & $289322 / 9$ & $0 / 97$ & $1 / 99$ \\
\hline Fertility Groups $\times$ Phosphorus Fertilizer & 9 & ${ }^{\mathrm{ns}} 214189 / 53$ & ${ }^{\mathrm{ns}} 0 / 72$ & ${ }^{\mathrm{ns}} 1 / 47$ \\
\hline Phosphorus Fertilizer $\times$ Fertility Groups $\times$ Year & 9 & ${ }^{\mathrm{ns}} 278446 / 49$ & ${ }^{\mathrm{ns}} 0 / 94$ & ${ }^{\mathrm{ns}} 1 / 91$ \\
\hline Area $\times$ Group $\times$ Phosphorus Fertilizer & 27 & ${ }^{\mathrm{ns}} 59086 / 98$ & ${ }^{\mathrm{ns}} 0 / 26$ & ${ }^{\mathrm{ns}} 0 / 53$ \\
\hline Area $\times$ Group $\times$ Phosphorus Fertilizer $\times$ Year & 27 & ${ }^{\mathrm{ns}} 153626 / 15$ & ${ }^{\mathrm{ns}} 0 / 52$ & ${ }^{\mathrm{ns}} 1 / 06$ \\
\hline Error $\mathrm{C}_{2}$ & 108 & $96440 / 96$ & $0 / 32$ & $0 / 67$ \\
\hline (CV \%) & & $14 / 06$ & $7 / 6$ & $8 / 56$ \\
\hline
\end{tabular}

Table 4. Compound variance analysis quality properties canola in fertility group soil absorption phosphorus over $>10$ ppm

\begin{tabular}{|c|c|c|c|c|}
\hline \multirow{2}{*}{ Change sources } & \multirow{2}{*}{ Degree freedom } & \multicolumn{3}{|c|}{ Mean squares } \\
\hline & & Oil yiled & Oil percentage & Protein percentage \\
\hline Year & 1 & $17067642 / 4^{* *}$ & $137 / 05^{*}$ & $265 / 21^{*}$ \\
\hline Repetition $\times$ Year & 6 & $12929 / 8^{* *}$ & $2 / 86^{*}$ & $5 / 53^{*}$ \\
\hline Area(A) & 3 & $6014990 / 8^{* *}$ & ${ }^{\mathrm{ns}} 3 / 55$ & $\begin{array}{ll}\mathrm{ns} & 6 / 88 \\
\end{array}$ \\
\hline Year $\times$ Area & 3 & $4598100 / 1^{* *}$ & ${ }^{\mathrm{ns}} 2 / 28$ & ${ }^{\mathrm{ns}} 4 / 42$ \\
\hline Error(A) & 18 & $31977 / 30$ & $4 / 16$ & $8 / 06$ \\
\hline Soil Phosphorus Fertility Groups(B) & 3 & $730475 / 2^{* *}$ & ${ }^{\mathrm{ns}} 2 / 24$ & ${ }^{\mathrm{ns}} 4 / 33$ \\
\hline Fertility Groups $\times$ Area & 3 & $1002115 / 95^{* *}$ & ns $2 / 85$ & ${ }^{\mathrm{ns}} 5 / 51$ \\
\hline Area $\times$ Fertility Groups & 9 & $380892 / 86^{* *}$ & ns $1 / 07$ & ${ }^{\mathrm{ns}} 2 / 08$ \\
\hline Year $\times$ Area $\times$ Fertility Groups & 9 & $782979 / 09^{* *}$ & ${ }^{\text {ns }} 0 / 95$ & ${ }^{\mathrm{ns}} 1 / 84$ \\
\hline Error(B) & 72 & $32201 / 05$ & $1 / 11$ & $2 / 15$ \\
\hline Phosphorus Fertilizer Treatment (C) & 3 & ${ }^{\mathrm{ns}} 255872 / 71$ & ${ }^{\mathrm{ns}} 0 / 97$ & ${ }^{\mathrm{ns}} 1 / 87$ \\
\hline Phosphorus Fertilizer Treatment $\times$ Year & 3 & ${ }^{\mathrm{ns}} 332634 / 5$ & ${ }^{\mathrm{ns}} 0 / 97$ & ${ }^{\mathrm{ns}} 1 / 87$ \\
\hline Area $\times$ Phosphorus Fertilizer & 9 & ${ }^{\mathrm{ns}} 275098 / 5$ & ${ }^{\mathrm{ns}} 0 / 78$ & ${ }^{\mathrm{ns}} 1 / 51$ \\
\hline Area $\times$ Phosphorus Fertilizer $\times$ Year & 9 & ${ }^{\mathrm{ns}} 357628 / 09$ & ${ }^{\mathrm{ns}} 1 / 02$ & ${ }^{\mathrm{ns}} 1 / 97$ \\
\hline ErrorC $_{1}$ & 36 & $373591 / 68$ & $1 / 05$ & $2 / 105 / 90$ \\
\hline Fertility Groups ×Phosphorus Fertilizer & 9 & ${ }^{\mathrm{ns}} 276574 / 83$ & ${ }^{\mathrm{ns}} 0 / 78$ & ${ }^{\mathrm{n} s} 1 / 51$ \\
\hline Phosphorus Fertilizer $\times$ Fertility Groups $\times$ Year & 9 & ${ }^{\mathrm{ns}} 359547 / 28$ & ${ }^{\mathrm{ns}} 1 / 02$ & ${ }^{\mathrm{ns}} 1 / 97$ \\
\hline Area $\times$ Group $\times$ Phosphorus Fertilizer & 27 & ns $76296 / 78$ & ${ }^{\mathrm{ns}} 0 / 28$ & ${ }^{\mathrm{ns}} 0 / 55$ \\
\hline Area $\times$ Group $\times$ Phosphorus Fertilizer $\times$ Year & 27 & ${ }^{\mathrm{ns}} 198371 / 63$ & ${ }^{\mathrm{ns}} 0 / 56$ & ${ }^{\mathrm{ns}} 1 / 09$ \\
\hline Error $\mathrm{C}_{2}$ & 108 & $124530 / 56$ & $0 / 35$ & $0 / 68$ \\
\hline (CV \%) & & $18 / 15$ & $7 / 94$ & $8 / 81$ \\
\hline
\end{tabular}


Table 5. The mean comparison two year, number of saddle bags, number of seeds in the saddlebags, weight of each 1000 seeds, seeds functioning, in phosphorus deferment treatments, in regions with fertility (<3ppm) for applied test (L.S.D)

\begin{tabular}{|c|c|c|c|c|c|}
\hline Phosphorus Fertilizer Treatment kg / ha & Region1 & Region2 & Region3 & Region4 & Regions mean \\
\hline & \multicolumn{2}{|c|}{ Number of sheath } & & & \\
\hline 0 & a28 & $\mathrm{a} 30$ & a29 & a29 & $\mathrm{a} 29$ \\
\hline 25 & a28 & a36 & a33 & a29 & a36 \\
\hline 50 & $\mathrm{a} 44$ & a44 & a41 & a41 & $\mathrm{a} 40$ \\
\hline \multirow[t]{2}{*}{75} & a39 & a39 & a39 & $\mathrm{a} 40$ & a38 \\
\hline & \multicolumn{4}{|c|}{ Number of sheath } & \\
\hline 0 & a26 & a32 & a32 & a31 & a30 \\
\hline 25 & a25 & a24 & a28 & a27 & a26 \\
\hline 50 & a24 & a27 & a27 & a26 & a26 \\
\hline \multirow[t]{2}{*}{75} & a21 & a27 & a26 & $\mathrm{a} 24$ & a25 \\
\hline & \multicolumn{4}{|c|}{ Weight of each 1000 seeds (gr) } & \\
\hline 0 & $\mathrm{a} 2 / 55$ & $\mathrm{a} 2 / 44$ & $\mathrm{a} 2 / 54$ & $\mathrm{a} 2 / 5$ & $\mathrm{a} 2 / 51$ \\
\hline 25 & $\mathrm{a} 2 / 47$ & $\mathrm{a} 2 / 58$ & $\mathrm{a} 2 / 5$ & $\mathrm{a} 2 / 54$ & $\mathrm{a} 2 / 52$ \\
\hline 50 & $\mathrm{a} 2 / 35$ & a2/44 & a2/4 & $\mathrm{a} 2 / 39$ & $\mathrm{a} 2 / 40$ \\
\hline \multirow[t]{2}{*}{75} & $\mathrm{a} 2 / 43$ & $\mathrm{a} 2 / 5$ & $\mathrm{a} 2 / 3$ & $\mathrm{a} 2 / 45$ & $\mathrm{a} 2 / 42$ \\
\hline & \multicolumn{4}{|c|}{ Seeds functioning (kg/ha) } & \\
\hline 0 & $\mathrm{a} 455 / 25$ & a337/25 & a524 & a523 & a460 \\
\hline 25 & a333/5 & a499 & $\mathrm{a} 461 / 5$ & a378 & a418 \\
\hline 50 & a373 & a396/5 & $\mathrm{a} 442 / 25$ & $\mathrm{a} 410 / 25$ & $\mathrm{a} 405 / 5$ \\
\hline 75 & a367/75 & a464/25 & $\mathrm{a} 428 / 75$ & a466 & a432 \\
\hline
\end{tabular}

*The effect treatment no significant for properties no mention amount (L.S.D)

Table 6. The mean comparison two year, oil percentage, protein percentage, oil yield in different treatment phosphorus in area for fertility (3-6 ppm) for benefit of test (L.S.D)

\begin{tabular}{|c|c|c|c|c|c|}
\hline Phosphorus Fertilizer Treatment kg / ha & Region1 & Region2 & Region3 & Region4 & Regions mean \\
\hline & \multicolumn{4}{|c|}{ Oil percentage } & \\
\hline 0 & a44 & a44 & a44 & $\mathrm{a} 44 / 2$ & a44 \\
\hline 25 & $\mathrm{a} 44 / 5$ & $\mathrm{a} 44 / 4$ & a44 & $\mathrm{a} 44 / 5$ & $\mathrm{a} 44 / 4$ \\
\hline 50 & $\mathrm{a} 47$ & a47 & a46 & a47 & $\mathrm{a} 46 / 5$ \\
\hline \multirow[t]{2}{*}{75} & a48 & a48 & $\mathrm{a} 48 / 3$ & a48 & $\mathrm{a} 48 / 2$ \\
\hline & \multicolumn{4}{|c|}{ Protein percentage } & \\
\hline 0 & a24/25 & $\mathrm{a} 24 / 2$ & a24/3 & $\mathrm{a} 24 / 2$ & $\mathrm{a} 24 / 2$ \\
\hline 25 & a24/45 & a24/5 & a24/4 & a25 & a24/6 \\
\hline 50 & a24/5 & a24/4 & a24/5 & a24/5 & a24/5 \\
\hline \multirow[t]{2}{*}{75} & a25 & a25/2 & a25 & a25/4 & a25/2 \\
\hline & \multicolumn{4}{|c|}{ Protein percentage } & \\
\hline 0 & a182/6 & a212 & a194/2 & a195 & a196 \\
\hline 25 & a118/26 & a213 & a155 & a156/4 & a161 \\
\hline 50 & a122 & a185 & a156 & a159/4 & a155/6 \\
\hline 75 & a202 & a276 & a225 & a224 & a232 \\
\hline
\end{tabular}

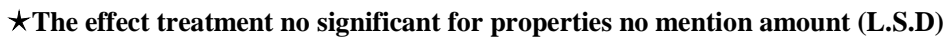


Table 7. The mean comparison two year, oil percentage, protein percentage, oil yield in different treatment phosphorus in area for fertility (6-10ppm) for benefit of test (L.S.D)

\begin{tabular}{|c|c|c|c|c|c|}
\hline Phosphorus Fertilizer Treatment kg / ha & Region1 & Region2 & Region3 & Region4 & Regions mean \\
\hline & \multicolumn{4}{|c|}{ Oil percentage } & \\
\hline 0 & a29 & a29 & $\mathrm{a} 28 / 7$ & a29/3 & a29 \\
\hline 25 & a44 & a44 & $\mathrm{a} 42 / 75$ & $\mathrm{a} 44 / 25$ & $\mathrm{a} 43 / 75$ \\
\hline 50 & a33 & a33 & a36/6 & a32/7 & a33 \\
\hline \multirow[t]{2}{*}{75} & a31 & a31 & $\mathrm{a} 30 / 6$ & a30/84 & a31 \\
\hline & \multicolumn{4}{|c|}{ Protein percentage } & \\
\hline 0 & $\mathrm{a} 25 / 2$ & a25 & a25 & a25 & a25 \\
\hline 25 & $\mathrm{a} 25 / 2$ & $\mathrm{a} 25 / 3$ & $\mathrm{a} 25 / 2$ & $\mathrm{a} 25 / 4$ & $\mathrm{a} 25 / 3$ \\
\hline 50 & a26 & a26 & $\mathrm{a} 25 / 7$ & $\mathrm{a} 26 / 3$ & a26 \\
\hline \multirow[t]{2}{*}{75} & a26/25 & a26/4 & $\mathrm{a} 26 / 5$ & a26 & $\mathrm{a} 26 / 3$ \\
\hline & \multicolumn{4}{|c|}{ Oil yield (kg/ha) } & \\
\hline 0 & a130 & a159 & a203/5 & a194 & a172 \\
\hline 25 & a134 & a250/5 & a236/5 & a246 & a217 \\
\hline 50 & a101 & a174 & a172 & a165/4 & a153 \\
\hline 75 & a148 & a154 & a156/6 & a162/4 & a155/3 \\
\hline
\end{tabular}

*The effect treatment no significant for properties no mention amount (L.S.D)

Table 8. The mean comparison two year, oil percentage, protein percentage, oil yield in different treatment phosphorus in area for fertility (over 10ppm) for benefit of test (L.S.D)

\begin{tabular}{|c|c|c|c|c|c|}
\hline Phosphorus Fertilizer Treatment kg / ha & Region1 & Region2 & Region3 & Region4 & Regions mean \\
\hline & \multicolumn{4}{|c|}{ Oil percentage } & \\
\hline 0 & a39 & a39 & a39 & a39 & a39 \\
\hline 25 & $\mathrm{a} 42 / 5$ & a42 & $\mathrm{a} 43$ & $\mathrm{a} 42$ & $\mathrm{a} 42 / 4$ \\
\hline 50 & a30 & a30 & a30 & a30 & a30 \\
\hline \multirow[t]{2}{*}{75} & a36 & a36 & a36 & a36 & a36 \\
\hline & \multicolumn{4}{|c|}{ Protein percentage } & \\
\hline 0 & a25/3 & a25/4 & $\mathrm{a} 25$ & a25 & $\mathrm{a} 25 / 2$ \\
\hline 25 & a26/3 & a26/2 & a26/3 & a26 & a26/2 \\
\hline 50 & a27/3 & $\mathrm{a} 27 / 2$ & a26/4 & a27 & a27 \\
\hline \multirow[t]{2}{*}{75} & a27/4 & a27/6 & a27/3 & $\mathrm{a} 27 / 2$ & a27/4 \\
\hline & \multicolumn{4}{|c|}{ Oil yield (kg/ha) } & \\
\hline 0 & $\mathrm{a} 185 / 4$ & a206 & $\mathrm{a} 233$ & $\mathrm{a} 255$ & $\mathrm{a} 220$ \\
\hline 25 & a171 & a186/3 & a197 & $\mathrm{a} 204$ & a190 \\
\hline 50 & a205/5 & a228 & $\mathrm{a} 255 / 4$ & $\mathrm{a} 217$ & $\mathrm{a} 226 / 5$ \\
\hline 75 & a298/2 & a250 & a264 & $\mathrm{a} 249$ & a265 \\
\hline
\end{tabular}

$\star$ The effect treatment no significant for properties no mention amount (L.S.D)

Table 9. Coordination between attributes investigation

\begin{tabular}{|c|c|c|c|c|c|c|}
\hline Attributes & $(1)$ & & & & & \\
\hline Straw.ph(1) & 1 & $(2)$ & & & & \\
\hline Seed.ph(2) & $0 / 72^{* *}$ & 1 & (3) & & & \\
\hline Seed. Yield(3) & $0 / 56^{* *}$ & $0 / 60^{* *}$ & 1 & (4) & & \\
\hline Oil.percentag(4) & $-0 / 54^{* *}$ & $-0 / 35^{* *}$ & $-0 / 53^{* *}$ & 1 & (5) & \\
\hline Oil yield(5) & $0 / 28^{*}$ & $0 / 45^{* *}$ & $0 / 79^{* *}$ & ${ }^{\mathrm{ns}} 0 / 06$ & 1 & (6) \\
\hline Protein percentage(6) & $0 / 84^{* *}$ & $0 / 90^{* *}$ & $0 / 60^{* *}$ & $-0 / 53^{* *}$ & $0 / 34^{* *}$ & 1 \\
\hline
\end{tabular}

ns, **, *, respectively, non significant, significant in probability surfaces one and five percentage.

\section{Result}

Phosphate fertilizer does not have meaningful effect on the percentage of oil, but in soils with high amount of phos- 
phate it is a little absorbable. Proper use of fertilizer causes improvement in the CANOLA oil production and the oil function. Phosphate fertilizer does not have meaningful effect on the percentage of CANOLA protein in all groups of phosphorous fertility soil. The amount of CANOLA protein is effected by phosphate fertilizer very little. There is a negative coordination between percentage of oil and percentage of protein in $\mathrm{B}$. $\mathrm{N}$. seed and with reduction in the percentage of oil, the percentage of protein increases. Coordination between oil percentage and oil function is weak and non meaningful but there is a strong and meaningful coordination between oil function and seed function. Therefore maybe the best way for increasing the oil production is seed function in each unit level.

\section{References}

[1] Rody. D., S. Rahmanpour, and F. Javidfar. (2012). CANOLA cultivation. Published by programming office media for agricultural Jehad ministry extension.

[2] Ahmadi, M. and F, Javedanfar. (2010). Nutrition of CANOLA oil plant, oil seeds rape committee-Tehran.

[3] Dehshiri, A. (2011). CANOLA cultivation. Agricultural Research Organization. Promotion deputy. Office for production program for technical extension and publication.

[4] Morshedi, A. H., Rezaee, M. J. Melekoti. (2014). Methods of preparation of nutritious oil seed. First part. CANOLA proper use. Technical publication No. 115. Agricultural training publication. Tat deputy. Agricultural ministry. Keraj-Iran.

[5] Bose, T. (2013). Effect of nitrogen, phosphorus and potassium on growth, yield and oil content of mustard (Brassica juncea). www.Indian industry. com. 14. Nev. 2009.

[6] Holmes, M. R. J. and Ainsley, A. M. (2010). Fertilizer requirements of spring oilseed rape. journal of the science of food and Agriculture, 28, 301-310.

[7] Holmes, M. R. J. and Ainsley, A. M. (2010). Seedbed fertilizer requirements of winter oilseed rape. Journal of the science of food and Agriculture, 24, 657-66.

[8] Wetter. L. R, Ukrainetz, H. and Downey, P. K. (2014). The effect of chemical fertilizers on the content of oil protein and glucosinolates in Brassia including rapeseed. Proceedings of the conference on Rapeseed and Rapeseed products st. Adele. Canada 92-112.

[9] Gupta, S. K. D. and Das, K. (2010). Effect of level and time of application of N, P and K on yield and oil content of rape (Brassiacampestris) www. sea of India. com. 13. Nev. 2009.

[10] Singh- U. B. and Tomar, S. P. (2010). Response of mustard to varying irrigation levels. Spacing and fertilizer application. Indian Journal of Agronomy. 88, 465-7.

[11] Grant, C. A. and L. D. Bailey. (2013). Fertility management in canola production. j.plant, sci. 73: 651-670.

[12] Pinkerton, A. (2012). Critical phosphrus con centrations in oilseed rape (Brassica napus) and Indian mustard (Brassica Juncea) Aus. J. of Exp. Agric. 31: 107-130.

[13] MirzaKhani, M. M. Ardekani, A. Ayeneband, A. H. Shirani rad. (2012). Effect of dual seed insemination with Azetobakter and MEKORIZA fungus (Mushroom) and different level of nitrogen, and phosphorus use on spring cultivation Safflower. Thesis of Islamic Azad University-Takestan Branch. Volume one. Third number. Pages 1 to 13.

[14] Jessen, W. (2013). The effect of phosphate fertilizer on summer rape when sown at different times. Zeitschrift fur pflanzenernahrung and Dungung, 190, 153-9.

[15] Majumdar, D. K. And Sandhu, A. S. (2005). Effect of time of sowing and fertilizer on the growth, development, quality characteristics and chemical composition of rapeseed (Brassica campestris, Brown sarson) www.trade-India.com. 7. Nev. 2009.

[16] Finlayson, A. J., Christ, T. C. M., and Downey, R. K. (2003). Changes in the nitrogenous components of rape seed (Brassica napus) grown on a nitrogen and sulphur deficient soil. www.ars.usda. gov. 14.Nev. 2009.

[17] Mohamadi Nikpour, A. R. (2013). Effect of cultivation date and density on the function and function component of Safflower in Mashad area. Thesis for Master in agriculture. Mashhad.

[18] Ojagloo, F. F., Ferahvash, A., Hussion, and M. Pour Yosef. (2012). The effect of insemination of bio fertilizer Azetobactor and fertile Phosphate on the safflower function. Science magazine-agricultural science speciality. Islamic Azad Univewrsity-Tabriz Branch. First year. No. 3. Autumn 1386. Pages 39 to 51.

[19] Gavahi, M. A. Shjie, and D. Ashidi. (1984). Analysis of effect of application of difference amount of potassium and sulfur on the percentage of CANOLA spring oilseeds rape. First scientific articles seminar symposium- industrial plant oil application in Iran. Pages 146 to151.

[20] Sajed, A., H. Hussiani Moghadam, D. AhmadiAval. (2014). Effect of plastic covering of soil, space in cultivation and the amount of phosphate and potassium fertilizer on the growth and function of seed and oil in medical pumpkin. National conference articles symposium on the medical plant. Tehran 24-26 Bahman 188. 